\title{
VET MODERNISATION ALIGNED WITH PRE-TECHNOLOGICAL AND OCCUPATIONAL PRE-HIGH EDUCATION
}

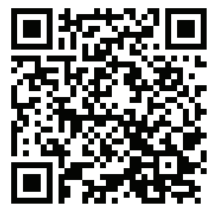

To cite this article:

\author{
Valentyna Radkevych, Dr. Sc., Prof. \\ Director, Institute of Vocational Education and Training, \\ National Academy of Educational Science of Ukraine, \\ Kyiv, Ukraine \\ ipto_info@ukr.net \\ https://orcid.org/0000-0002-9233-5718
}

Radkevych, V. (2018). VET modernisation aligned with pre-technological and occupational pre-high education. Education: Modern Discourses, 1, 118-128.

https://doi.org/10.32405/2617-3107-2018-1-11

\begin{abstract}
The article represents VET modernisation problem as pre-technological and occupational pre-high education. The aim is to ground innovative changes priority approaches in educational sub-systems aligned with Sustainable Development Strategy "Ukraine-2020", Copenhagen Declaration, Bruges Communique, Torino Process, etc. The article provides characteristics of educational trends emphasising technological education for senior high school students modernisation. Modern approaches on personalisation technological education, professional career guidance for schoolers are envisaged. It grounds the necessity for structural changes in schools based on cooperation with enterprises, VET schools and HEIs. It emphasises the need to modernize VET in accordance with modern economy and education trends. The increasing prestige mechanism for working professions and professional (vocational) education as a whole is revealed. The article defines VET's aim and its organization-pedagogical conditions, namely: VET schools management decentralization; setting marketing services; implementing VET education quality monitoring system; multi-source financing etc. The specifics for transition to applied training model targeting a person's needs, national and regional LMs are considered. The attention is drugged to broad use of dual education within employers' engagement; setting flexible training entities for formal, in-formal and non-formal professional education programs realisation. It specifies the specifics of creating information-educational environments, inclusive education conditions in VET schools. It emphasises competence-based occupational, educational and assessment standards development, designing new hi-tech qualifications, creating a New occupations and professions register, including "green" ones. Inter-disciplinary approach for projecting socio-cultural component of VET content importance is outlined and the need for occupational pre-high education modernization is examined.
\end{abstract}

Key words: competence approach; future specialists; modernization; occupational prehigh education; technological education; VET; VET quality assurance. 


\section{INTRODUCTION. PROBLEM STATEMENT}

Among priority education reforming directions the prominent place belongs to vocational education and training (VET) that is connected with technological education for high school students, on the one hand, and on the another one - with occupational pre-high education for training junior specialists for different sectors of economy. In this regard, the aim of VET modernization is to ensure its new quality for satisfy the needs of modern Ukrainian society and economy in qualified specialists and, respectively, increase the level of society's social understanding and country's economy safety. It will give the possibility to get quality results in VET - motivated active qualification-seeking students aimed at continual professional development, self-realisation and career promotion (Vocational education and training, 2018).

The study of these processes is aligned with Sustainable Development Strategy "Ukraine-2020" statements for main priority innovation changes, namely: country, economy, society development; safety increase for country, citizens, business; responsibility and social justice upturn. Accordingly, the forward move is conducted in four vectors to upgrade intellectual professional potential, getting the citizens ready to solving sustainable development problems. First of all, it will contribute social relationship improvement that results on trust increase to Ukraine as a European country with stable business climate, unique place for division of labour in the world.

The ground for VET modernization in Ukraine is international and domestic documents results such as "Key skills-2020", announced at Worldwide economic forum in Davos in 2018; priority directions of technological education and VET stated in UNESCO Strategy 2016-2020. In particular, in accordance with the above mentioned Strategy priority directions of technological education and VET strategy changes include the following: employment and entrepreneurship level increase among the youth; promotion of justice and gender equality, facilitate the transition to "green economy" and society sustainable development.

Globalization challenges, political and economic transformations, change in value systems make VET open to international cooperation. A particular role in this context belongs to the strategies outlined in the Copenhagen Declaration (2002) to ensure the strengthening of VET and occupational pre-high education European focus (mobility promotion, qualifications transparency, skills and qualifications recognition, quality assurance etc.). Equally important in providing VET modernization in Ukraine is the Bruges Communique (2010), which outlines the renewed strategic approaches and objectives of EU educational policies together with their employment policies objectives. The value of Bruges Communique provisions is, first of all, in defining the vision for VET and occupational pre-high education development, in particular, by ensuring their attractiveness for students and their parents, education quality awareness, and confidence in knowledge and skills acquisition meeting the requirements of labour market (LM) and is the basis for productive employment. This document also states that additionally to initial qualification it is important to ensure the quality of VET and occupational prehigh education, namely: mastering additional programs to achieve the highest level of qualification in the chosen field, to deepen the competence; work-based learning (WBL) activities at enterprises and companies; deepening interaction with social partners; VET internationalization to involves the acquisition of special competences (e.g. knowledge of foreign languages) and infrastructure development to ensure VET graduates' professional mobility, their progressive professional experience acquisition etc. 
Innovative context of changes in VET system is also widely discussed within the framework of European forums on education quality issues, in particular, in order to define clear objectives and methods of the EU countries' education quality managing characteristic, development of competence-based qualification requirements and social partnership etc. It contributed to implementing the number of measures in Ukraine on European standards and principles introduction to support quality assurance in VET and occupational pre-high education taking into account LM requirements and specialists' professional competence (Radkevych, 2017). In particular, the National Qualifications Framework (NQF) was developed and implemented, the competence-based professional and educational standards were created and tested, diagnostic tools for evaluating learning outcomes were defined, including certification of qualifications, and relationship expansion for education institutions and LM were introduced for positive impact on improving VET and occupational pre-high education quality at national and international levels. Thus, the aim of the article is to ground modern approaches to VET modernization in Ukraine.

\section{LITERATURE REVIEW}

Literature review represents the study of reforming problems for national education in the light of modern challenges in the discussions and writings of V. Andrushchenko, G. Filipchuk, L. Grynevych, V. Kremen, V. Lugovyi, N. Nychkalo, S. Sysoieva, O. Spirin, O. Spivakovsky, O. Topuzov, Y. Zinkovskiy et al. In particular, the successful implementation of educational transformations, as the academician V. Kremen correctly contends, among other things, needs to clear up the understanding of civilization changes objective, the progress of social development, a person's new demands. Changes in education should maximize a person's readiness for life and activities in the 21st century (Kremen, 2017). According to O. Topuzov for implementing the European integration mission of Ukrainian education it is necessary to develop an entry-map of the Ukrainian education system into the European educational environment, as well as a comprehensive program for following 10-year development and reforming of Ukraine's education system (Topuzov, 2017).

Conceptual bases of junior specialists' vocational training of in technical schools and colleges are described in the scientific works of S. Alekseeva, A. Kalensky, A. Kozak, N. Kolisnyk, S. Kravets, P. Luzan, T. Pashchenko, O. Shcherbak, N. Shulga, N. Vanina, O. Yamkovy and others.

The quality ensuring issue of technological education and future handicraft and technologies teachers' training for their further professional activity are violated in the researches of M. Advagia, I. Androschuk, O. Avramenko, O. Kobernyk, A. Kolomiets, M. Korts, V. Korkok, L. Makarenko, L. Orshansky, I. Smirnova, A. Tsiny, I. Voytovych, S. Yaschuk, V. Yurzhenka and others.

Severality the training of future qualified specialists in VET institutions were covered in the works of home scientists (L. Basyl, O. Baseliuk, O. Humenniy, R. Gurevych, N. Kulalaieva, A. Kononenko, T. Pyatnychuk, G. Romanov, L. Shevchuk, L. Vysotskaya, L. Yershova, D. Zakatnov and others) and the foreign ones (N. Bednarczyk, T. Dissinger, V. Golubovsky, A. Kusainov, A. Popova, D. Robertson, A. Shklyar, F. Szlosek, S. Tella, M. Wallace, etc.). Foreign aspects of VET development are widely represented in the researches of N. Baseluk, N. Bidyuk, O. Borodiyenko, S. Leu, O. Lokshyna, L. Pukhovskaya, N. Pazuri, O. Radkevych and others. In particular, the research interest in the implementing a roadmap for VET development in the EU countries (O. Borodiyenko, L. Pukhovska, O. Radkevych, S. Leu, 2017) is stated. 
The above mentioned works constitute methodological-theoretical and methodic basis for conducting researches on VET modernization of vocational education and ensuring its aligning with technological and occupational pre-high education.

\section{METHODOLOGY}

To achieve the aim, the following methods were used: theoretical - scientific literature and legislation document on reforming issues analysis; empirical-diagnostic: discussions, interviews, questionnaires of managers and pedagogical staff of professional (vocational) education schools on the need for network optimization issues, innovations implementation and use in the educational process; observational - monitoring professional (vocational) education schools functioning in modern conditions.

\section{MAIN RESULTS}

An important vector for the domestic VET modernization is to ensure its continuity as a key factor in achieving a graduate's ideal - an individuality of a specialist with highly developed sense of self-esteem, civility, tolerance, high level of professionalism, mobility, self-realization, readiness for continuous professional development. Therefore, there is a problem of substantiating innovative changes in technological, VET and occupational pre-high education.

Modernization changes in domestic technological education are based on global trends requirements like creativity, mobility and critical thinking. Among the most popular technological educational trends in Ukraine, it is possible to outline: STEM technologies for transferring laboratory classes from one school to another, things Internet ("smart" objects communication network), digital books, distance learning, game-learning, personalized training, video-focused learning, part-time training, peer assessment, adaptive learning, etc. In this context, the purpose of technological education is to ensure the integral physical, intellectual, social and spiritual development of a student's personality, his/her technological culture formation, cultivating the internal need for respect to work, training for a successful subject-transformation activity.

For the stated aim realisation, the handicraft and technologies teachers are important, according to V. P. Kurok, are intended not only for training students to perform technological operations and use technical means, work with complex equipment, but also to form them as creative, technically educated personalities, familiar with various types of transformative human activities, general structure and use of technology, prospects for their further development (Kurok, 2018). Accordingly, the importance of ensuring technological education personalization is actualized within involving qualitative professional counselling for students in order to enhance the motivation for professional career choice and building. For this purpose, the vocational guidance content should include a flexible information system about the world of professions, a set of professional counselling techniques and technologies, psychological and pedagogical diagnosis, career coaching and in-advance upgrading under dynamic LM changes.

There is an urgent need to move away from passive handicraft training and reproductive working activities and create the evolving competency-oriented system of technological education for mastering creativity methods and ICT for senior high school students. Given this, for upgrading technological education content it is expedient to make certain structural changes, for example, to create "Educational and production 
complexes" for closer cooperation of general secondary education institutions and enterprises, as well as VET schools and high education institutions (HEIs). It is also important to ensure effective cooperation between education and production actors. That cooperation involves theoretical teaching for high school students from different schools on selected profiles of technological areas at a resource training institution, and practical - at an enterprise, since general secondary education institutions are not able to provide various profiled professional training.

At general secondary education institutions, it is also necessary to implement project technologies, developmental learning methods, interactive forms of educational and cognitive activity with research elements at high-tech production, subject-development environment targeted at students' studying the specifics of professional activity in various spheres under learning conditions. We emphasize that only a comprehensive solution for the above listed tasks will allow us to get as close as possible to modern technological education's aim realisation.

The basis for domestic VET modernization changes is, first of all, global economic trends, namely: energy paradigm change that causes the emerging market demand for new types of professional activity; transiting to technological paradigm 4.0 and, in particular, digital economy that positively affects the growth of world-wide demand for hightech education (Radkevych, 2018), as well as educational trends, including: education internationalization; life-long learning; personalized education pathways; social justice and gender equality; inclusive education; informal and informal education; mobile and distance learning; distributed responsibility for VET funding, etc.

The most important vector for VET modernization in Ukraine is in general grounding workers' professions and professional (vocational) education prestige increasing ways and means in general. There are some determinants of the vector, like: modern employers' growing requirements to VET graduates' quality; LM changes, when some professions disappear and others emerge rapidly; the out-of-date material and technical base at VET institutions, that enables them to form modern skills; graduates' unpreparedness for selfemployment at non-sustainable LM; high demands of Ukrainian youth to conditions and wages and caused splash of labour migration to EU countries, etc. Overall, the positive image of professional education is being damaged. As a result, there is the decrease in the number of secondary schools graduates entering professional (vocational) education institutions in 2017 will be reduced to $20 \%$. It makes the raised issues even deeper.

The results of professional (vocational) education institutions students' survey testify their different motives for studying here, in particular: they are tired of studying in a secondary school $(4.3 \%)$, they want to facilitate the entry to HEIs avoiding final external testing $(18.5 \%)$, they haven't entered a HEI $(7 \%)$. This testifies to the ineffectiveness of professional guidance impact on the student youth for them to choose the direction of future professional self-realization. At the time there is the transition to professional career counselling system for students (Radkevych, 2017).

In this context, VET modernization is intended to turn itself into an important factor for the innovation potential sustainable growth for national industry and society as a whole, create the pre-conditions for building "knowledge-based economy", as well as a person's professional movement. In this regard, the necessity of structural and content changes in VET is determined. First of all, it is about creating VET's effective structure, updating its content according to occupational standards, implementing competenceoriented educational process, and forming modern educational environment. 
Taking into account the sector specifics of VET schools activities, their location and group filling, the optimization of educational network should take place in accordance with the following principle: in the cities of regional importance one-profile professional colleges and lyceums can be set along with multi-profile ones, and, in the cities of rayon significance, urban-type settlements, villages - only multi-profile with high-tech training centres for the purpose of providing equal and qualitative access to VET, obtaining full and partial qualifications, including new professions, can take place.

Accordingly, the significance of professional (vocational) education purpose set in the Law of Ukraine "On Education" is updated, in particular, formation and development of a person's needed professional competences for his/her professional activity on a certain profession in the relevant field, ensuring his/her competitiveness and mobility at LM, and prospects for life-long career development (Zakon Ukrainy "Pro osvitu", 2017). A significant role in the process of achieving this purpose is given to:

- VET schools management decentralization that requires project-oriented approach to management, activities updating for regional VET councils according to regional educational policy development;

- increasing of education-productive clusters efficiency and stakeholders' participation in professional training process, modernizing the material and technical base of institutions, etc.;

- creating marketing services for LM demand and supply predictive forecasting, obtaining information on possible volumes, structure of the necessary jobs and occupations, as well as qualitative managing decisions;

- introduction of a VET quality monitoring system to assess VET schools competitiveness level basis on their educational, production, financial and economic activities indicators and determined results;

- different-level-source funding.

Concerning the transition to a mixed funding system of VET, a survey was conducted among the heads of professional (vocational) education institutions in Ukraine. The obtained results testify to their divergent attitude towards different sources funding (Fig. 1).

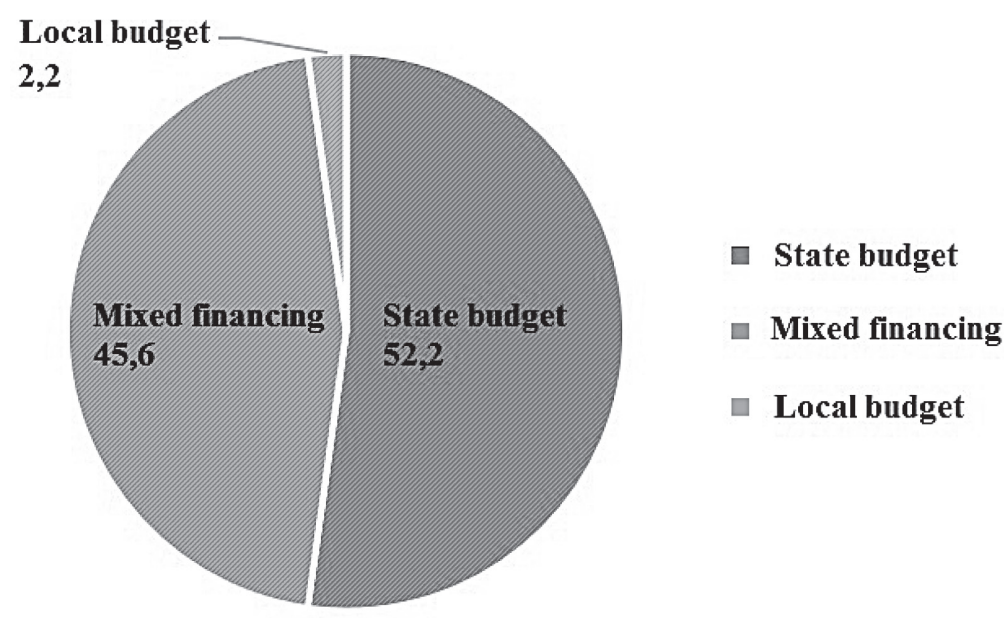

Figure 1. VET financing from different sources 
Thus, the largest percentage of respondents (52.2\%) favoured state budget financing, and the smallest percentage $(2.2 \%)$ - local budget financing. This testifies to the lack of vocational (vocational) education institutions heads' confidence in the local selfgovernment bodies and authorities in terms of financing their activities.

VET modernization in Ukraine will also, as N. Nychkalo notes, use the European system of credits accumulation and transfer to provide LLL, as well as the possibility of transition from VET to HE (Nychkalo, 2017).

One of VET modernization priorities is the transition to a practice-oriented model of professional training of future specialists with more complete approximation of its social and economic components to a person's needs and national and local LM requirements. This will enable: broader use of dual VET form by increasing the applied training content component for specialists in real working environment; to create flexible educational structures able to implement full-time, mixed, distance forms of formal and informal VET programs based on special software.

In this context, the scientific interest belongs to foreign experience on combining professional training with practice at enterprises. For example, in the Netherlands, the practice, in one case, may take $20-60 \%$ of training time, and in the other, professional training should be at least $60 \%$ as an addition to professional activity at the workplace (Radkevych, 2016). The practice-oriented phenomenon of apprenticeship, carried out at enterprises, VET schools in most EU countries (Leu, 2016).

The transition to the systematic introduction of ICTs in all types of educational institutions will take place. For that, information and educational environments will be created in VET schools. They are aimed at forming professionals-innovators and citizens capable for professional activity of national and European standards level. Encouraging inclusive VET will also take place. For students with special needs, more favourable conditions for obtaining a profession will be created. Special training programs, correctional and rehabilitation measures will be developed, and appropriate psychological and pedagogical support will be provided.

Domestic VET modernization needs competence-based content via: introducing modern pedagogical design principles; developing competence-based occupational, educational and assessment standards; creation of a new List of professions and occupations, including "green" ones; designing new qualifications for high-tech production. VET content updating will take into account the widespread labour intellectualization that will require the system of fundamental and professional knowledge and skills that will be a good basis for new quality level a person's mindset formation. It will support fast self-improvement, adaptation to new requirements and conditions of professional and entrepreneurial activity.

For a specialist's personality innovative potential development, the significance of the sociocultural VET content component will increase that will facilitate new forms of social and civil life assimilation in the dynamically changing world. The interdisciplinary approach will be used to create educational programs for facilitating the optimal theoretical training combination based on content integration. It will provide more efficient form for integral competence development in a particular field of professional activity. For staff training and retraining short modular-based educational programs will be used; the proportion of applied training and traineeship will increase to improve a person's ability of performing particular works or professional activity in a qualified manner. 
The implementation of these tasks is ensured by active participation of pedagogical staff in the generating ideas processes of and their practical use for future qualified professionals training improvement (Radkevych, Luzan \& Kravets, 2017). In this regard, it is important to introduce innovative VET forms, in particular: open modular-based professional training; virtual enterprises; instructional farms, business centres, etc.

VET modernization is ensured via using innovative pedagogical technologies by teachers and masters, namely: personal development; simulation game; modular; cases; designing; contextual; coaching; ICT for centralized electronic methodological support of game learning (gaming) and/or simulations.

Under current conditions, the development of a specialist's occupational pre-high education approach together with $5 \mathrm{NQF}$ level qualifications is especially significant. The new direction needs scientific substantiation of its specificity, content, forms and methods. Taking this into consideration, the actual tasks are: studying the state-of-arts for junior specialists' professional training in technical schools and colleges; theoretical substantiation of VET standardisation concept for junior specialists; VET standards development and testing for junior specialists; creation and implementation of methodological recommendations for technical schools and colleges' pedagogical staff on competence-based professional training for junior specialists.

The need for modernization processes in occupational pre-high education is conditioned by the global nature of advanced technologies use in production and, consequently, by production processes changes and, thus, workers' functions. For that, they must be able to combine a skilled worker's and manager's qualities for designing a product, provide with resources the production process, independently carry out work with maximum correspondence to customers' interests, assess its quality, etc. In this regard, technical schools and colleges must respond quickly to modern LM needs and dynamic technical and technological changes in the economy, transfer new qualifications into the format of new competencies.

\section{CONCLUSIONS}

Having regard to the above, one can conclude that for a new type of national economy with innovative production processes and quality assessment systems, fundamental changes are needed in the sector of future skilled professionals training for professional activity at the level of national and European standards. It is facilitated by ensuring the continuity of technological, professional and occupational pre-high education that will enable creation preconditions for forming a critical mass of innovative type specialists with high level of readiness for personal and professional success and a clear civil position that can lead Ukraine to a qualitatively new level of socio-economic development. Therefore, the importance of highly professional and mobile specialists training, retraining and advanced training in the LM is updated.

The results of tasks and directions analysis within technological, professional (vocational) and occupational pre-high education prove the significance of introducing in the training process the followings: modern methods of competence-based content design and development for "flexible" specialists training, new competence-based qualifications and educational standards integration; person-developing pedagogical technologies for increasing students' motivation to studying, improve their cognitive activity, develop key and professional competencies; the project training technologies to increase the teachers' 
and students' readiness for project activity; dual approaches under high-tech industry to promote applied training for future specialists based on establishing efficient social partnership; innovative management technologies to achieve efficient organizational culture at training institutions; digital teaching aids to improve educational and methodological support for training process; design methods for creating education-informational environment at training institutions to ensures all processes development to form teachers' and graduates' ICT competence and culture; professional career development counselling systems for students to affect their career competence positive dynamics etc.

Consequently, based on taken into account a person's, society's and state's requests to improve technological, professional (vocational) and occupational pre-high education quality, their compliance with national and international standards, it is necessary to make the following changes:

- transition to early person's professionalization by providing high-quality professional guidance services based on a personally oriented approach and motivation to progressing in professional careers, life-long self-realization;

- promoting social justice and gender equality for all educational process actors at training institutions, based on increasing women's and girls' access to training programs, creating conditions for implementing equal employment opportunities;

- transition to education competence-based content design taking into account needs of industry 4.0;

- employer-assist educational programs development to ensure flexible pathways for obtaining full and partial qualifications needed to enter LM skills, including selfemployment;

- improving training institutions' educational environment to promote their greater openness, accessibility, availability, innovation, business orientation;

- transition to systematic ICT implementing at training institutions of all types through design and setting online platforms with educational and methodological materials for high school students, students and teachers; distance courses; digital textbooks; content-libraries; SMART-complexes; multimedia learning and communications;

- expansion of training institutions and business development frameworks via integration into educational-industry clusters to coordinate regional training institutions' educational activities, rational use of means, attracting additional investments in VET and creating new workplaces, prevent funding for non-efficient educational programs or duplicated ones;

- qualifications certification introduction to enhance education quality by implementing educational programs based on RPL and entrance testing, etc.;

- decentralised education development management within automatic performance of training institutions' activities, funding mechanisms improvement, transfer of control powers, as well as licensing and accreditation ones to regional specialized institutions;

- transition to mixed different levels budgets financing system for educational institutions to support increasing the number of their founders, etc.

In summary it can be concluded that VET modernisation aligned with its continuity in technological and occupational pre-high education will promote its transformation into accessible, flexible, high-quality, innovative, inclusive, attractive educational subsystem for students and adults and the one that is significantly integrated into socioeconomic processes, open to life-long professional career development. 


\section{REFERENCES}

Borodiienko, O., Pukhovska, L., Radkevych, O. \& Leu, S. (2017). Dorozhnia karta profesiinoi osvity i navchannia $\mathrm{v}$ krainakh Yevropeiskoho Soiuzu [Roadmap of vocational education and training in EU countries]. Profesiina pedahohika, 13, 129-138.

Kremen, V. H. (ed.) (2016). Suchasne myslennia y osvita: metodolohichnyi kontsept [Modern thinking and education: a methodological concept]. Naukove zabezpechennia rozvytku osvity v Ukraini: aktualni problemy teorii i praktyky (do 25-richchia NAPN Ukrainy) [Scientific support for the development of education in Ukraine: actual problems of theory and practice (to the 25th anniversary of the National Academy of Sciences of Ukraine)]. Kyiv: Vydavnychyi dim “Sam”, 8-16.

Kurok, V. I. (2018). Pidhotovka maibutnikh uchyteliv trudovoho navchannia ta tekhnolohii $\mathrm{u}$ konteksti novoi ukrainskoi shkoly [Handicraft and technologies teachers training in the context of New Ukrainian School]. Aktualni problemy tekhnolohichnoi i profesiinoi osvity, 11-12.

Leu, S. O. (2016). Uchnivstvo v profesiinii osviti y navchanni krain YeS [Apprenticeship in vocational education and training in EU countries]. Profesiina pedahohika, 12, 116-127.

Nychkalo, N. H. (2017). Neperervna profesiina osvita u konteksti teorii liudskoho kapitalu [Lifelong professional education in the context of the human capital theory]. Naukove zabezpechennia rozvytku osvity $v$ Ukraini: aktualni problemy teorii i praktyky (do 25-richchia NAPN Ukrainy) [Scientific support for the development of education in Ukraine: actual problems of theory and practice (to the 25th anniversary of the National Academy of Sciences of Ukraine)]. Kyiv: Vydavnychyi dim “Sam”, 246-259.

Profesiino-tekhnichna osvita (2018). Suchasna profesiina osvita. Kontseptualni zasady reformuvannia profesiinoi osvity Ukrainy [Modern professional education. Conceptual basis for VET reforming in Ukraine]. Profesiino-tekhnichna osvita, 2-12.

Radkevych, O. (2016). [Legislative ensuring education and professional training in the Netherlands]. Profesiina pedahohika, 12, 127-135.

Radkevych, V. (ed.) (2017). Modernizatsiia profesiinoi osvity i navchannia v konteksti yevrointehratsii: naukovyi suprovid [Modernisation of vocational education and training in the Eurointegration context]. Naukovo-metodychne zabezpechennia profesiinoi osvity i navchannia, 27-32.

Radkevych, V. (ed.) (2017). Profesiina osvita i navchannia: yevropeiskyi kontekst rozvytku [Vocational education and training: European development context]. Profesiina pedahohika, 14, 5-14.

Radkevych, V. O., Luzan, P. H. \& Kravets, S. H. (2017). Standartyzatsiia profesiinoi osvity $\mathrm{v}$ konteksti yevropeiskoi intehratsii [Standardization of vocational education in the context of european integration]. Naukove zabezpechennia rozvytku osvity $v$ Ukraini: aktualni problemy teorii i praktyky (do 25-richchia NAPN Ukrainy) [Scientific support for the development of education in Ukraine: actual problems of theory and practice (to the 25th anniversary of the National Academy of Sciences of Ukraine)]. Kyiv: Vydavnychyi dim “Sam”, 259-267.

Radkevych, V. (ed.) (2018). Naukovo-metodychnyi suprovid modernizatsii vitchyznianoi systemy profesiinoi ta fakhovoi peredvyshchoi osvity u konteksti yevrointehratsiinykh protsesiv [Scientific and methodological support of national vet and professional prehigh education modernization within the framework of European integration processes]. Profesiina pedahohika, 15, 5-15. 
Topuzov, O. M. (2017). Zabezpechennia yakosti zahalnoi serednoi osvity: na shliakhu do yevropeiskyi standartiv [The guarantee of the quality of the comprehensive secondary education: on the way to the European standards]. Naukove zabezpechennia rozvytku osvity v Ukraini: aktualni problemy teorii i praktyky (do 25-richchia NAPN Ukrainy) [Scientific support for the development of education in Ukraine: actual problems of theory and practice (to the 25th anniversary of the National Academy of Sciences of Ukraine)]. Kyiv: Vydavnychyi dim "Sam", 183-191.

Zakon Ukrainy "Pro osvitu" (2017) [Law of Ukraine "On Education"]. Uriadovyi kurier, 186, 9-19. 